\title{
Measuring Oligopsony Market Power in the Italian Electricity Market: Preliminary Results
}

\author{
Simona Bigerna • Carlo Andrea Bollino
}

Published online: 10 July 2014

(C) International Atlantic Economic Society 2014

\section{JEL Classification $\mathrm{C} 90 \cdot \mathrm{D} 00 \cdot \mathrm{N} 10$}

In this research we analyze the unilateral market power on the demand side in the Italian wholesale electricity market. In this market there are generators on the supply side, traders (retailers), and end-users, such as large industrial firms on the demand side. We define agents bidding on the demand side simply as "consumers" (assuming profit maximizing behavior). This is the first attempt in the literature to measure empirically oligopsonistic behavior in a electricity market, using individual consumer bid data.

There may exist two reasons for oligopsonistic behavior. Firstly, given the existence of generator market power on the supply side (Wolak, American Economic Review, 2003), it is conceivable that consumers could try to achieve lower prices when there is abundance of supply. Secondly, there exists vertical integration in electricity markets, which can result in supply market power mitigation (e.g. Newbery, Energy Journal, 2005; Bushnell et al., American Economic Review, 2008). This implies that there may exist market power on the demand side, too.

Previous estimations in the literature have usually used ex-post market data. The shortcoming is that simultaneity between supply and demand hinders separate estimations of competitive-behavior effects and input-supply high-elasticity effects (e.g. Bergman and Brännlund, Review of Industrial Organization, 1995). Unfortunately, direct estimation of a production function (Murray, Review of Economics \& Statistics, 1995) does not solve the problem because measuring the input value of marginal product is not sufficient to assess oligopolistic market power.

The novelty of our research is to estimate residual supply elasticities in an oligopsonistic market structure using individual bids submitted to the Italian Market Operator (GME) in the day ahead energy market. In our analysis we take into account the main

\footnotetext{
S. Bigerna $\cdot$ C. A. Bollino $(\bowtie)$

Department of Economics, University of Perugia, Perugia, Italy

e-mail: carloandrea.bollino@unipg.it

S. Bigerna

e-mail: simona.bigerna@unipg.it
} 
five consumers (out of a total of 221 listed consumers on the demand side) who express about half of market demand. We measure oligopsony market power, computing the hourly price elasticity of the ex-post residual supply curve for each consumer, which is the difference between total supply and demand of all other consumers.

In particular, we compute arc elasticity around the equilibrium market price for each hour. Under Italian market rules, all consumers pay a unique system marginal price, which is set as the average of different zonal supply prices received by generators, arising from market segmentation when there is transmission congestion. This simplifies our analysis because market outcomes on the demand side are insulated from transmission line congestion issues.

We interpret the inverse of the hourly ex-post residual supply elasticity as a Lernertype index, i.e. a measure of the potential ability that each consumer possesses to exploit oligopsonistic market power in order to lower the hourly price below marginal willingness to pay the last megawatt-hour purchased in the Italian day ahead energy market. We think that market power of oligopsonistic consumer may be exercised only in some periods of the day in which supply is particularly abundant. In the Italian market this may happen in two distinct cases when there is: i) slack in the market, typically during off-peak hours; ii) plentiful supply of renewable energy sources during daytime peak hours, typically displacing thermal generation. If in these periods supply structure is characterized by a positive supply elasticity (i.e. increasing marginal costs) then a consumer can attempt to reap better price behaving as an oligopsonist.

Thus we analyze the Lerner index for all 8760 hours in each year in the period 2010-2011. Our results show that there exists oligopsonistic market power which can be empirically measured on average around 3.8\% in 2010 and 5.3\% in 2011 (all values are statistically significant). This means that Italian consumers are able to mark down their willingness to pay for electricity on average 3-5\% with respect to market price. Results are quantitatively similar for all five main consumers. In addition we find that individual consumer Lerner index values are higher during working day peak hours, in the $4.5-5 \%$ range in 2010 and $7.5-10 \%$ in 2011 . It is interesting that oligopsony power tends to be higher in 2011 than 2010 during peak hours: this can be explained with the threefold increase of renewable supply (mainly PV) that occurred in the same period, resulting in abundant supply with priority dispatching. This situation favors consumer exercise of market power.

In conclusion, our analysis shows that consumers definitely bid lower prices below their willingness to pay and that this behavior, based on significantly elastic residual supply, is more likely to occur during weekday peak hours. Future research should test for collusive behavior, analyze consumer conjectural variations, and take into account explicitly the problem of transmission line congestion. 